\title{
Toxicity of Commercial Neem Extract to Earthworms (Pheretima peguana)
}

\author{
Ptumporn Muangphra ${ }^{1}$ and Ravi Gooneratne ${ }^{2}$ \\ ${ }^{1}$ Biology Department, Faculty of Science, Silpakorn University, Nakhon Pathom 73000, Thailand \\ ${ }^{2}$ Faculty of Agriculture and Life Science, Lincoln University, Canterbury, Lincoln 7647, New Zealand
}

Correspondence should be addressed to Ravi Gooneratne, ravi.gooneratne@lincoln.ac.nz

Received 1 December 2010; Revised 7 April 2011; Accepted 27 June 2011

Academic Editor: Marco Trevisan

Copyright ( 2011 P. Muangphra and R. Gooneratne. This is an open access article distributed under the Creative Commons Attribution License, which permits unrestricted use, distribution, and reproduction in any medium, provided the original work is properly cited.

\begin{abstract}
The $\mathrm{LC}_{50}$ of commercial neem extract (Sadao Thai III containing azadirachtin; NEEM) on filter paper in the earthworm Pheretima peguana at $48 \mathrm{~h}$ and $72 \mathrm{~h}$ was 3.79 and $3.33 \mu \mathrm{g} \mathrm{cm}^{-2}$, respectively. In earthworms exposed to five NEEM concentrations from 0.39 $\left(\sim 10 \%\right.$ of $\left.48-\mathrm{h} \mathrm{LC}_{50}\right)$ to $3.13\left(\sim 80 \%\right.$ of $\left.48-\mathrm{h} \mathrm{LC}_{50}\right) \mu \mathrm{g} \mathrm{cm}^{-2}$, the radial thickness of the epidermis and body wall significantly $(P<.05)$ decreased, and thickness of intestinal epithelium increased but only at high doses, approximately 25 -fold above the concentration permitted for use as an insecticide in field applications $\left(0.09 \mu \mathrm{g} \mathrm{cm}^{-2}\right)$. NEEM significantly $(P<.05)$ increased the number of binucleated coelomocytes in the micronucleus test (detects chromosomal aberrations) at $3.13 \mu \mathrm{g} \mathrm{cm}{ }^{-2}$, approximately 35 -fold higher than the recommended dose, but it did not cause coelomocyte DNA single-strand breaks in the comet assay. Thus, NEEM is cytotoxic (increase in binucleates through the inhibition of cytokinesis) but not genotoxic to earthworm coelomocytes. This study demonstrates that the recommended dosage of commercial neem extract as an insecticide in agricultural practices is safe for earthworms.
\end{abstract}

\section{Introduction}

The most active chemical of neem extract (Sadao Thai III; NEEM) is azadirachtin (Aza), which belongs to the tetranortriterpenoid group of organic compounds. It functions as an ecdysone blocker and a feeding deterrent for some insect pests. There is a perception that NEEM is an environmentally friendly insecticide, so it is often used in high concentrations, and this can lead to a heavy load of NEEM in soil. High NEEM soil concentrations can cause chronic toxicity to nontarget organisms such as crustaceans (Daphnia magna and Hyalella azteca) [1] through leaching from soil into waterways. NEEM has also been shown to induce genotoxicity in rodents $[2,3]$ and fish [4]. These effects raise concern over the safe use of NEEM as a pesticide in agricultural practices.

Although earthworms are often used in terrestrial ecotoxicity evaluation [5], there is little information available on the effects of NEEM on earthworm immune competent cells and histology of the epidermis, skin, body wall, and intestinal lining. In earthworms, coelomocytes are the circulating leukocytes present in the coelomic cavity and play an important role in immune defense. They have been used to study the effect of genotoxicants such as nickel $(\mathrm{Ni})$ and cadmium (Cd) $[6,7]$ on earthworms. The genotoxicity of NEEM to earthworm coelomocytes has not been reported.

DNA damage induced in mammalian and aquatic species by chemical and physical agents can lead to the appearance of micronuclei in erythrocytes of mice [8] and piscines [9]. Micronuclei are cytoplasmic chromatin masses resembling minute nuclei, formed when a whole chromosome or acentric chromosomal fragments lag during anaphase and fail to become incorporated into daughter-cell nuclei during cell division [10]. Micronuclei are formed under the influence of genotoxic clastogens (which cause chromosomal breaks) and aneugens (which affect the spindle apparatus and can lead to a loss of the whole chromosome) prior to mitosis [11]. Micronuclei can be detected with the in vivo micronucleus test, a well-established assay in genotoxicity testing and human biomonitoring that also detects other 
nuclear anomalies such as binucleated, blebbed, notched, and lobed nuclei.

Binucleate cell formation occurs in abnormal cytokinesis [12] and during cell proliferation. Salehzadeh et al. [13] reported the similarity between Aza and colchicine was that both phytochemicals prevented the polymerization in vitro of mammalian tubulin. Because of the mechanism of action of NEEM, binucleated cells were investigated.

The comet assay has been used for genotoxicity assessment of DNA single-strand breaks [14] to detect even low level DNA damage in single cells [15]. It is based on the further migration of damaged DNA during electrophoresis, with the DNA then resembling a "comet" with a brightly fluorescent head and a long tail region that increases with severity of DNA damage. It has been used to assess DNA damage in earthworms, for example, Eisenia fetida exposed to $\mathrm{Ni}$ [6], Aporrectodea longa to soil spiked with benzo[a]pyrene (B[a]P) and/or lindane [16], and Amynthas diffringens, Aporrectodea caliginosa, Dendrodrilus rubidus, Eisenia fetida, and Microchaetus benhami to Cd [7]. Both the micronucleus test and comet assay have been proposed as biomarkers of DNA damage.

Earthworms are resilient organisms and can live in soil containing significant concentrations of chemicals, including some persistent insecticides [17]. Ecologically, this is relevant, because several species of birds and mammals feed on earthworms, and therefore, any chemical accumulation can potentially lead to biomagnification. Amaral et al. [18] reported variation in the radial thickness of chloragogenous tissue and intestinal epithelium, which are the major toxicant depositories in earthworms $[19,20]$. To our knowledge, the toxicity of NEEM on the histology of these tissues has not been previously reported.

The objectives of the present study were to evaluate (1) the acute toxicity of NEEM to Pheretima peguana, (2) the subacute toxicity of NEEM by evaluating (i) DNA damage including chromosomal aberrations (micronucleus test), (ii) DNA single-strand breaks (comet assay), and (iii) variation in thickness of epidermis, body wall and intestinal epithelium, and (3) the relative sensitivity of these biomarkers to Pheretima peguana exposed to NEEM.

\section{Materials and Methods}

2.1. Earthworms. Earthworms (Pheretima peguana, Lumbricidae, Oligochaeta) were sourced from a commercial supplier. The worms were maintained in large plastic boxes (containing moist soil supplemented with cow dung) in the laboratory at $28 \pm 1{ }^{\circ} \mathrm{C}$ and $65 \%$ humidity, with a $12 \mathrm{~h}$ light/dark cycle and fed weekly with watermelon and acclimatized for 2 weeks. Adult worms (identified by the presence of a clitellum), weighing 300-500 mg, were allowed to depurate their gut contents on damp filter paper for $24 \mathrm{~h}$ prior to the experiments to avoid contamination during harvesting of coelomocytes.

2.2. Reagents. Commercial neem extract (Sadao Thai III) was obtained from Thaineem Products Co., Bangkok, Thailand, and pure Aza, the active insecticide in NEEM, from
Sigma-Aldrich, USA. Cadmium chloride $\left(\mathrm{CdCl}_{2}\right)$ (Fluka Chemical Corp., Milwaukee, USA) was used as a positive control.

2.3. Testing Solutions. Varying concentration of Aza solutions, namely, 0.00005\%, 0.00010\%, 0.00020\%, 0.00030\%, $0.00040 \%, 0.00050 \%, 0.00060 \%$, and $0.00070 \%(w / v)$ Aza were prepared from commercial $0.1 \%(\mathrm{w} / \mathrm{v})$ Aza-containing NEEM. These Aza testing solutions were determined by high performance liquid chromatography (HPLC) and contained Aza at the concentrations of 8.31, 16.61, 33.22, 49.83, 66.44, $83.05,99.66$, and $116.27 \mathrm{mg} / \mathrm{L}$, respectively. Distilled water was used as the control.

The HPLC analyses were conducted using a Pursuit C18 column $\left(5 \mu \mathrm{m}, 250 \times 4.6 \mathrm{~mm}^{2}\right.$ I.D. $)$ fitted to the Agilent 1100 Series HPLC System equipped with 1100 binary pump, 1100 diode array and UV detector. The samples $(20 \mu \mathrm{L})$ were autoinjected into the HPLC. The mobile phase used was acetonitrile-water $(40: 60 ; \mathrm{v} / \mathrm{v})$, at a flow rate of $1 \mathrm{~mL} \mathrm{~min}^{-1}$, while the UV signals were recorded at $210 \mathrm{~nm}[21,22]$. The standard Aza was eluted at a retention time of $10.5 \mathrm{~min}$. The chromatograms and data were acquired and processed with the HP Chemstation Data System (Scientific Equipment Center, Kasetsart University, Thailand).

2.4. Acute Toxicity. After 24-h depuration, earthworms were rinsed in distilled water and dried on filter paper. A total of 140 earthworms were exposed to either distilled water (control; $n=20$ ) or one of six concentrations (based on a preliminary study) of NEEM containing Aza $(n=20$ per concentration). Earthworms were weighed and each placed in a glass container $(2 \times 9 \mathrm{~cm})$ lined with a $9-\mathrm{cm}-$ diameter Whatman no. 1 filter paper. Filter papers were moistened with $3 \mathrm{~mL}$ of one of the different concentrations of Aza: 0, 33.22, 49.83, 66.44, 83.05, 99.66, and $116.27 \mathrm{mg} \mathrm{L}^{-1}$. These concentrations are equivalent to Aza exposures of 0 , $1.57,2.35,3.13,3.92,4.70$, and $5.48 \mu \mathrm{g} \mathrm{cm}^{-2}$ of filter paper. All experiments were performed at room temperature. The percentage mortality was determined at 48 and $72 \mathrm{~h}$. Earthworms were considered dead when they did not respond to touch of the anterior region. The data were analyzed using Probit analysis on SPSS statistical software to determine the concentration at which $50 \%$ and $10 \%$ mortality occurred.

2.5. In Vivo Dose-Effect Relationship. The in vivo dose-effect relationship was assessed in coelomocytes of 48 earthworms, using the micronucleus test, whereby micronuclei and binucleate frequencies are determined. Each earthworm was exposed to NEEM containing one of five Aza concentrations ( $n=6$ per treatment), well below the $\mathrm{LC}_{50}$ concentration for $48 \mathrm{~h}$ in filter paper studies as described above for the subacute study. Final Aza concentrations were 0.39 ( $\sim 10 \%$ of 48-h LC $_{50}$ concentration), 0.78, 1.57, 2.35, and 3.13 ( $\sim 80 \%$ of $48-\mathrm{h} \mathrm{LC}_{50}$ concentration) $\mu \mathrm{g} \mathrm{cm}^{-2}$ filter paper. Distilled water was used as a negative control $(0 ; n=6)$ and a single dose of $\mathrm{CdCl}_{2}\left(0.01 \mu \mathrm{g} \mathrm{cm}^{-2} ; n=6\right)$ as the positive control. In Thailand, the highest concentration of Aza permitted for use in the field is $0.09 \mu \mathrm{g} \mathrm{cm}^{-2}$. Therefore, a pure Aza 
concentration of $0.09 \mu \mathrm{g} \mathrm{cm}^{-2}(n=6)$ was also used in the study.

At $48 \mathrm{~h}$, three earthworms from each concentration, including the positive and negative controls and the pure Aza group, were removed from the filter paper, rinsed in distilled water and slightly dried on a paper towel for coelomocyte collection. Each treatment had three replicates. Coelomocytes were enumerated and examined for cell viability, chromosomal aberration (micronucleus test) and DNA single-strand breaks (comet assay). The remaining three earthworms were used for histological studies of the epidermis, body wall, and intestinal epithelium. The bodyweights of all earthworms were recorded.

2.5.1. Coelomocyte Collection. Three earthworms from each group were exposed to extrusion buffer [23], and the coelomocytes extruded through the dorsal pores were used for the assays.

2.5.2. Coelomocyte Enumeration and Cell Viability. The extruded coelomocytes from three earthworms were transferred to ice-cold $\mathrm{Ca}^{2+}$ free Lumbricus balanced salt solution (LBSS) [24]. Cells were counted in a haemocytometer and the cell concentration adjusted to $10^{5}$ cells $\mathrm{mL}^{-1}$. Cell viability was determined with the trypan blue exclusion test after mixing an equal volume of coelomocyte suspension with $0.4 \%$ trypan blue (Sigma, USA) solution.

2.5.3. Micronucleus Test. An aliquot of $10 \mu \mathrm{L}$ coelomic fluid from each earthworm was smeared on a glass slide, with three slides from each earthworm for each concentration, and allowed to air dry. The coelomocytes were then fixed with methanolic fixative solution and stained with Wright Rapid Stain. A total of 3,000 small coelomocytes from three separate slides $\left(1,000\right.$ cells slide $\left.{ }^{-1}\right)$ from each earthworm per concentration were examined under a compound microscope at 1000x magnification to determine the mean micronuclei and binucleate frequency. The remaining coelomic fluid was used to study DNA single-strand breaks by the comet assay.

2.5.4. Comet Assay. Three microgel slides were prepared from the coelomocytes of three earthworms, based on the protocol of Singh et al. [25] modified by S. A. Reinecke and A. J. Reinecke [6]. All steps were conducted in dim light at $4^{\circ} \mathrm{C}$ to prevent additional DNA damage. An aliquot of $20 \mu \mathrm{L}$ coelomocyte cell suspension was carefully mixed with $75 \mu \mathrm{L}$ $0.5 \%(\mathrm{w} / \mathrm{v}$ in PBS, pH 7.3) low-melting agarose (LMA) at $40^{\circ} \mathrm{C}$, overlaid on microscopic slides precoated with $100 \mu \mathrm{L}$ normal melting agarose and immediately covered with a cover glass. Agarose was allowed to solidify by keeping slides on ice packs for $1 \mathrm{~min}$. Cover glasses were removed and $0.5 \%$ low-melting agarose (prepared in $40 \mathrm{mM}$ Tris$\mathrm{Cl}$ ) was layered on the slides and covered with a cover glass. Slides were then transferred onto ice packs for $1 \mathrm{~min}$. Cover glasses were removed and the slides kept in lysis buffer $(2.5 \mathrm{M} \mathrm{NaCl}, 100 \mathrm{mM}$ EDTA, $10 \mathrm{mM}$ Tris base, $1 \%$ Triton- $\mathrm{X}, \mathrm{pH} 10.0$ ) for $15 \pm 1 \mathrm{~h}$ in dark at $4^{\circ} \mathrm{C}$. Slides were then transferred to a tank containing electrophoresis buffer
(300 mM NaOH, 1 mM EDTA, pH > 13) for 20 min for DNA to unwind. Electrophoresis was carried out for $30 \mathrm{~min}$ at $12 \mathrm{~V}$ $(\sim 0.37 \mathrm{~V} / \mathrm{cm})$ and $300 \mathrm{mAmp}$. Next, slides were neutralized with a $0.4 \mathrm{M}$ Tris buffer ( $\mathrm{pH} 7.5)$ thrice at 5 -min intervals.

Slides were stained with $100 \mu \mathrm{L}$ of $20 \mu \mathrm{g} \mathrm{mL}^{-1}$ ethidium bromide for $5 \mathrm{~min}$ and washed with deionized water to remove excess stain. The slides were observed in a Nikon eclipse 80i fluorescent microscope with filter block UV2A (excitation filter $510-560 \mathrm{~nm}$, decroic mirror $575 \mathrm{~nm}$, emission $590 \mathrm{~nm}$ ). Images of comets were obtained with a digital camera (Nikon DXM 1200C) and analyzed with the software program LUCIA (Laboratory Universal Computer Image Analysis). At least 100 nonoverlapping comets per slide were captured randomly at 400x magnification and scored for the following comet parameters: tail DNA (TD) $\%$ (expressed as the percent of fluorescent intensity in tail), DNA tail length (TL; the distance from nuclear center to the end of comet tail), and DNA tail moment (TM; incorporates a measure of the smallest detectable size of migrating DNA (reflected in the comet tail length) and the number of relaxed/broken pieces (represented by the intensity of DNA in the tail)).

\subsubsection{Earthworm Transverse Section: Histology and Morphom-} etry. A 1-cm-thick earthworm transverse section posterior to the clitellum was excised ( $n=3$ earthworms for each NEEM Aza concentration and the control) and fixed for $24 \mathrm{~h}$ in Bouin fixative, dehydrated in $70 \%$ alcohol, cleared in methylbenzoate overnight, rinsed in benzene, embedded in paraffin, and sectioned at $7-\mu \mathrm{m}$ thickness. Sections were stained with haematoxylin and eosin. Ten serial sections per worm were used to quantify the radial thickness of the epidermis, body wall (epidermis and muscle), and intestinal epithelium, with each section divided into six regions as shown in Figure 1. In each region, the radial thicknesses of epidermis, body wall, and intestinal epithelium were measured under a compound microscope (100x and 400x magnification) for morphometry. Measurements were made by a single observer using an ocular micrometer. The average of six region measurements per section was calculated. Due to time constraints, the morphometric studies could not be performed in the earthworms exposed to the pure Aza groups.

2.6. Statistical Analyses. Results of the in vivo dose-effect relationship study are expressed as the mean and standard error of the mean (SEM) from three earthworms. Data were processed with SPSS Software version 11.5 and significant differences between different treatment groups were determined using one-way ANOVA and Tukey's multiple comparisons test. When normality failed, the Kruskal-Wallis $\mathrm{H}$ or Mann-Whitney $U$ test was performed. For all statistical tests, differences were considered significant if $P<.05$.

\section{Results}

3.1. Acute Toxicity. NEEM was toxic to Pheretima peguana in the filter paper contact test as evidenced by an increase in mortality with increasing concentrations. The $\mathrm{LC}_{50}$ and 


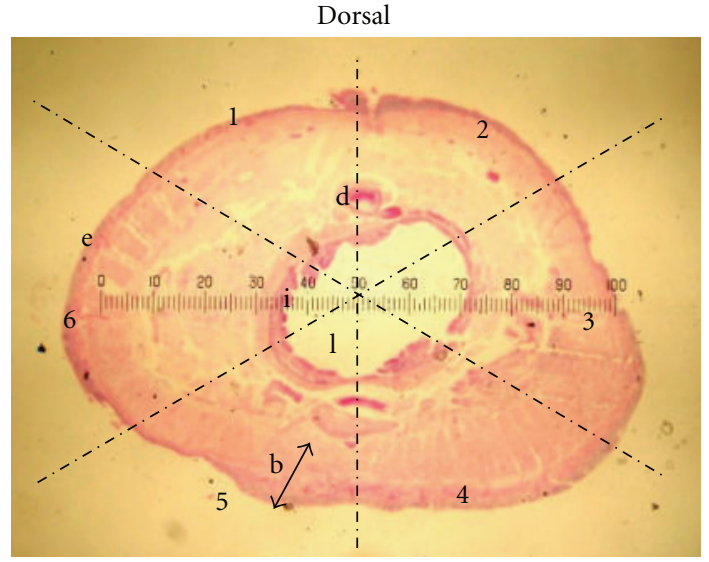

Ventral

FIGURE 1: Earthworm transverse section showing the epidermis, body wall and intestinal epithelium stained with haematoxylin and eosin $(\times 10)$. Nos. 1-6 show the regions where the radial thickness was measured. e: epidermis; b: body wall; i: intestinal epithelium; l: lumen; d: dorsal blood vessel.

$\mathrm{LC}_{10}$ of NEEM at $48 \mathrm{~h}$ to Pheretima peguana were 3.79 and $1.27 \mu \mathrm{g} \mathrm{cm}^{-2}$, respectively, and at $72 \mathrm{~h}$ were 3.33 and $0.84 \mu \mathrm{g} \mathrm{cm}^{-2}$, respectively (Figure 2 ). These concentrations are much higher than the recommended dose $\left(0.09 \mu \mathrm{g} \mathrm{cm}^{-2}\right)$ in the field.

\subsection{In Vivo Dose-Effect Relationship}

3.2.1. Coelomocyte Enumeration and Cell Viability. After $48 \mathrm{~h}$ exposure of earthworms to NEEM, extruded coelomocytes were counted and expressed as the number of cells per unit bodyweight. There was no significant difference in coelomocyte number per unit bodyweight between earthworms exposed to increasing concentrations of Aza and the controls (Table 1). The coelomocyte viability varied from 96 to $100 \%$.

3.2.2. Micronucleus Test. Micronuclei and binucleate numbers in coelomocytes exposed to distilled water (control), NEEM, pure Aza, and Cd (positive control) following a 48-h exposure are shown in Table 2. The number of binucleates increased significantly in earthworms exposed to the higher concentrations of NEEM (Aza $>2.35 \mu \mathrm{g} \mathrm{cm}^{-2}$ filter paper) and $\mathrm{Cd}\left(0.01 \mu \mathrm{g} \mathrm{cm}^{-2}\right)$. Numbers of micronuclei were significantly increased in earthworms exposed to the positive control, but not in those exposed to NEEM.

3.2.3. Comet Assay. TD\%, TL and TM in earthworm coelomocytes treated with Cd, pure Aza and NEEM are shown in Table 3. Earthworms exposed to the positive control Cd for $48 \mathrm{~h}, \mathrm{TD} \%$ and TM increased significantly (Table 3). No significant differences in TD\%, TL and TM were found in earthworms exposed to pure Aza and NEEM compared with the controls.

3.2.4. Histology and Morphometry. The effects of NEEM on Pheretima peguana histology are shown in Figure 3.

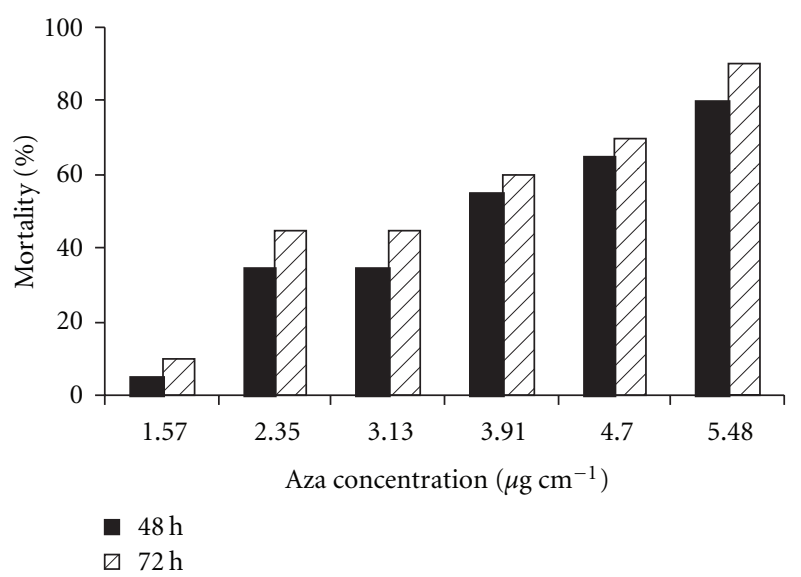

FIGURE 2: Earthworm mortality exposed to commercial neem extract containing Aza at 48 and $72 \mathrm{~h}$.

TABle 1: Change in coelomocyte numbers and coelomocyte viability of Pheretima peguana exposed to commercial neem extract (NEEM) containing Aza in a 48-h filter paper study.

\begin{tabular}{lccc}
\hline $\begin{array}{l}\text { NEEM containing } \\
\text { Aza concentration } \\
\left(\mu \mathrm{g} \mathrm{cm}^{-2}\right)\end{array}$ & $n$ & $\begin{array}{c}\text { No. of coelomocyte } \times \\
10^{6} \text { /body weight } \\
(\text { mean } \pm \text { SEM })\end{array}$ & $\begin{array}{c}\text { Coelomocyte } \\
\text { viability }(\%)\end{array}$ \\
\hline $0($ control $)$ & 3 & $1.69 \pm 0.15$ & 100 \\
0.39 & 3 & $2.44 \pm 0.39$ & $99.33 \pm 0.33$ \\
0.78 & 3 & $2.15 \pm 0.28$ & $98.67 \pm 0.33$ \\
1.57 & 3 & $1.49 \pm 0.29$ & $97.67 \pm 0.88$ \\
2.35 & 3 & $1.44 \pm 0.25$ & $97.33 \pm 1.20$ \\
3.13 & 3 & $1.32 \pm 0.33$ & $95.67 \pm 1.20$ \\
\hline
\end{tabular}

NEEM at and above $2.35 \mu \mathrm{g} \mathrm{cm}^{-2}$ Aza concentration on filter paper significantly increased the radial thickness of the intestinal epithelium (Figure 3(d)), but the effect was less than observed with the positive control $\left(\mathrm{Cd} 0.01 \mu \mathrm{g} \mathrm{cm}^{-2}\right.$; Table 4). In contrast, NEEM significantly decreased the radial thickness of body wall at and above $2.35 \mu \mathrm{g} \mathrm{cm}^{-2}$, and epidermis at $3.13 \mu \mathrm{g} \mathrm{cm}^{-2}$ concentration (Table 4 ). The Cd positive control, $0.01 \mu \mathrm{g} \mathrm{cm}^{-2}$, significantly increased the radial thickness of epidermis and intestinal epithelium but not of the body wall. Histological examination of transverse sections from the control group (Figure 3(a)) showed normal architecture and the intact nature of circular and longitudinal muscles. Earthworms exposed to $\sim 80 \% \mathrm{LC}_{50}$ for $48 \mathrm{~h}$ (Aza $3.13 \mu \mathrm{g} \mathrm{cm}^{-2}$ ) showed the neighboring cells in circular and longitudinal muscles to be discontinuous, separated by narrow to large gap junctions (Figure 3(b)).

\section{Discussion}

This study was conducted to determine whether NEEM, an "ecofriendly" pesticide, caused any cytotoxic or genotoxic effect on a nontarget terrestrial organism, the earthworm Pheretima peguana. In coelomocyte studies, viability always exceeded $96 \%$. This is in contrast to the study of Homa et al. [26] who reported that coelomocyte viability significantly 
TAble 2: Number of micronuclei and binucleates in coelomocytes following a 48-h exposure of Pheretima peguana to commercial neem extract (NEEM), pure Aza, and Cd in a filter paper study.

\begin{tabular}{|c|c|c|c|c|}
\hline \multirow{2}{*}{ Chemical agent } & \multirow{2}{*}{ Concentration $\left(\mu \mathrm{g} \mathrm{cm}^{-2}\right)$} & \multirow{2}{*}{$n$} & \multicolumn{2}{|c|}{ No. of cells with micronuclei/bionucleates per 1,000 cells } \\
\hline & & & Micronuclei & Binucleates \\
\hline Negative control & 0 & 3 & $0.33 \pm 0.33^{\mathrm{a}}$ & $2.00 \pm 0.56^{\mathrm{a}}$ \\
\hline Positive control $(\mathrm{Cd})$ & 0.01 & 3 & $4.67 \pm 0.67^{b}$ & $9.67 \pm 0.88^{c}$ \\
\hline Pure Aza & 0.09 & 3 & $0.33 \pm 0.33^{\mathrm{a}}$ & $3.00 \pm 0.58^{\mathrm{ab}}$ \\
\hline \multirow[t]{5}{*}{ NEEM } & 0.39 & 3 & $0.67 \pm 0.33^{\mathrm{a}}$ & $4.33 \pm 0.67^{\mathrm{ab}}$ \\
\hline & 0.78 & 3 & $1.00 \pm 0.58^{\mathrm{a}}$ & $4.33 \pm 0.88^{\mathrm{ab}}$ \\
\hline & 1.57 & 3 & $1.33 \pm 0.33^{\mathrm{a}}$ & $5.00 \pm 1.16^{\mathrm{ab}}$ \\
\hline & 2.35 & 3 & $2.33 \pm 0.67^{\mathrm{a}}$ & $5.67 \pm 0.67^{\mathrm{ab}}$ \\
\hline & 3.13 & 3 & $2.33 \pm 0.67^{a}$ & $6.33 \pm 0.67^{b c}$ \\
\hline
\end{tabular}

Within a column, data (mean \pm SEM) marked with the same letter are not significantly $(P>.05)$ different from each other.

TABLE 3: Comet assay results in Pheretima peguana coelomocytes following a 48-h exposure to commercial neem extract (NEEM), pure Aza, and $\mathrm{Cd}$ in filter paper.

\begin{tabular}{lccccc}
\hline Chemical agent & Concentration $\left(\mu \mathrm{g} \mathrm{cm}^{-2}\right)$ & $n$ & Tail DNA\% (TD\%) & DNA tail length (TL) & DNA tail moment (TM) \\
\hline Negative control & 0 & 3 & $7.72 \pm 1.44$ & $39.51 \pm 9.72$ & $3.75 \pm 1.38$ \\
Positive control $(\mathrm{Cd})$ & 0.01 & 3 & $16.79 \pm 1.61^{*}$ & $50.77 \pm 2.57$ & $9.84 \pm 1.42^{*}$ \\
Pure Aza & 0.09 & 3 & $5.17 \pm 0.43$ & $30.88 \pm 6.84$ & $2.02 \pm 0.50$ \\
NEEM & 0.39 & 3 & $7.91 \pm 1.61$ & $28.45 \pm 4.28$ & $1.73 \pm 0.03$ \\
& 0.78 & 3 & $9.11 \pm 0.51$ & $33.77 \pm 2.01$ & $2.16 \pm 0.05$ \\
& 1.57 & 3 & $5.17 \pm 0.69$ & $23.62 \pm 5.30$ & $1.64 \pm 0.50$ \\
& 2.35 & 3 & $6.59 \pm 1.03$ & $28.78 \pm 7.09$ & $2.94 \pm 0.77$ \\
\hline
\end{tabular}

Within a column data (mean \pm SEM) marked with asterisks are significantly $(P<.05)$ different from the control.

decreased following $\mathrm{Cu}, \mathrm{Pb}$, or $\mathrm{Cd}$ treatment at $1.32 \mu \mathrm{g} \mathrm{cm}{ }^{-2}$ filter paper doses.

Chandra and Khuda-Bukhsh [4] reported that Aza induced genotoxicity in Oreochromis mossambicus fish. Our results indicate that there is no significant difference in micronuclei between earthworms exposed to NEEM and pure Aza compared with the negative control, indicating that Aza did not cause chromosomal aberrations in coelomocyte DNA. However, NEEM at $3.13 \mu \mathrm{g} \mathrm{cm}^{-2}$ Aza concentration and the $\mathrm{Cd}$ positive control at $0.01 \mu \mathrm{g} \mathrm{cm}^{-2}$ concentration on filter paper significantly increased the number of binucleate coelomocytes (Table 2). This is in agreement with Anuradha et al. [27] who reported that Aza A, the major limonoid of neem seed extracts, induces depolymerization of actin leading to arrest of cells and subsequently apoptosis in a caspase-independent manner. This could be because Aza has chemical characteristics similar to colchicine, an antimitotic metabolite affecting synthesis and depolymerization of spindle fibers [28]. Therefore, binucleate appearance could be regarded as a biomarker of effects at higher exposure to NEEM (at $3.13 \mu \mathrm{g} \mathrm{cm}^{-2}$ ), which is about 35 -fold higher than the permitted use in the field $\left(0.09 \mu \mathrm{g} \mathrm{cm}^{-2}\right)$.

In the comet assay, neither NEEM nor pure Aza had an effect on TD\%, TL and TM compared with the negative control (Table 3) indicating that these chemicals do not cause DNA damage at the concentrations used in this study, which are higher than the concentrations used in the field.
In contrast, in Cd-exposed earthworms, the $\mathrm{TD} \%$ and $\mathrm{TM}$ were significantly higher than in the negative control at 48-h exposure. This is in agreement with Fourie et al. [7] who found that Cd damaged coelomocyte DNA of three earthworm species-Aporrectodea caliginosa, Dendrodrilus rubidus, and Eisenia fetida - in artificial soil-water medium at an exposure to Cd concentrations as low as $20 \mathrm{mg} \mathrm{L}^{-1}$.

The present study has shown that NEEM significantly decreased the thickness of body wall and epidermis and increased the thickness of intestinal epithelium of Pheretima peguana but only at high concentrations. Similar changes to the intestine have been reported in the earthworm Lumbricus terrestris exposed to volcanic soil with high $\mathrm{Cu}$ and $\mathrm{Fe}$ content [18]. The increased intestinal epithelial thickness may be interpreted as an adaptation of the earthworms to increased exposure to toxicants including NEEM, to protect the gut lining. According to Morgan et al. [20], morphological alterations in Dendrodrilus rubidus intestinal epithelium are a way coping with exposure to high metal concentrations. Collectively, such changes would affect the health of earthworms including changes to absorption and digestion of nutrients, behavior, and locomotion.

It is apparent that NEEM can damage the epidermis, body wall, and intestinal epithelium of the earthworms. The gaps in muscles in the body wall may be due to apoptosis leading to discontinuous muscle cells. Similar changes have been reported in earthworms exposed to tetraethyl lead 
TABle 4: Radial thickness of epidermis, body wall, and intestinal epithelium of Pheretima peguana exposed to commercial neem extract (NEEM) and Cd for $48 \mathrm{~h}$.

\begin{tabular}{lccccc}
\hline \multirow{2}{*}{ Agent } & \multicolumn{2}{c}{ Concentrations $\left(\mu \mathrm{g} \mathrm{cm}^{-2}\right)$} & $n^{*}$ & \multicolumn{2}{c}{ Radial thickness $(\mu \mathrm{m})$} \\
& & & Epidermis & Body wall & Intestinal epithelium \\
\hline Negative control & 0 & 30 & $32.02 \pm 0.36^{\mathrm{b}}$ & $309.67 \pm 1.54^{\mathrm{b}}$ & $19.19 \pm 0.50^{\mathrm{a}}$ \\
Positive control (Cd) & 0.01 & 30 & $35.10 \pm 0.22^{\mathrm{c}}$ & $303.89 \pm 1.15^{\mathrm{b}}$ & $63.97 \pm 1.66^{\mathrm{c}}$ \\
NEEM & 0.39 & 30 & $30.97 \pm 0.33^{\mathrm{b}}$ & $300.11 \pm 9.26^{\mathrm{b}}$ & $23.52 \pm 0.53^{\mathrm{a}}$ \\
& 0.78 & 30 & $30.18 \pm 70.69^{\mathrm{b}}$ & $297.53 \pm 4.26^{\mathrm{ab}}$ & $25.38 \pm 0.97^{\mathrm{a}}$ \\
& 1.57 & 30 & $29.98 \pm 0.47^{\mathrm{b}}$ & $293.57 \pm 6.65^{\mathrm{ab}}$ & $26.52 \pm 0.84^{\mathrm{a}}$ \\
& 2.35 & 30 & $29.19 \pm 0.84^{\mathrm{b}}$ & $278.64 \pm 1.54^{\mathrm{a}}$ & $48.05 \pm 2.01^{\mathrm{b}}$ \\
& 3.13 & 30 & $26.08 \pm 0.50^{\mathrm{a}}$ & $277.28 \pm 5.26^{\mathrm{a}}$ & $55.58 \pm 3.83^{\mathrm{b}}$ \\
\hline
\end{tabular}

Within a column, data (mean \pm SEM) marked with the same letter are not significantly $(P>.05)$ different from each other.

$* n=30$ is based on an average of six areas selected from each region, 10 serial sections per earthworm, from three earthworms per treatment.

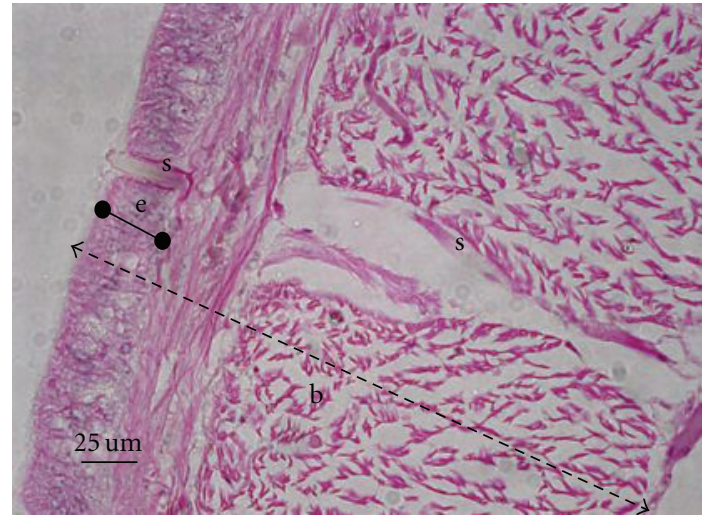

(a)

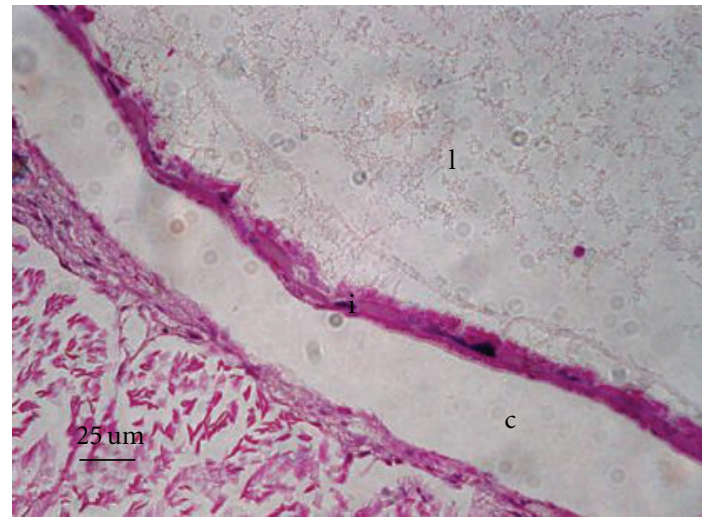

(c)

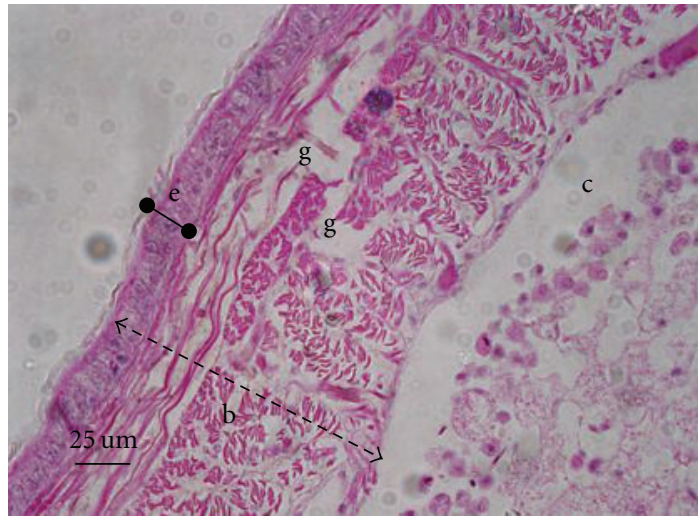

(b)

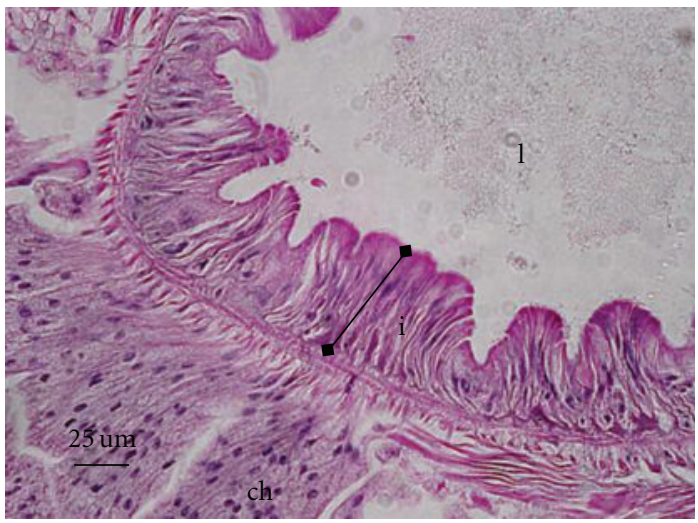

(d)

FIgURE 3: Histological changes in transverse sections of epidermis and body wall (a, b), and intestinal epithelium (c, d) in Pheretima peguana following a 48-h exposure to commercial neem extract (NEEM) containing $3.13 \mu \mathrm{g} \mathrm{cm}^{-2}$ Aza concentration on filter paper. (a) Negative control; intact muscles and epidermis. (b) Treated with NEEM showing expansion of spaces between the circular muscles and reduced epidermal and body wall thickness. (c) Control intestinal epithelium. (d) Treated with NEEM showing increased intestinal epithelial thickness. e: epidermis; b: body wall; i: intestinal epithelium; l: lumen; c: coelom; ch: chloragogenous tissue; g: gap between neighboring cells in circular and longitudinal muscles; s: setae. (Bar for each section is $25 \mu \mathrm{m}$.)

and lead oxide [29] and the organophosphorous pesticide profenofos [30].

Thus although NEEM and pure Aza were not genotoxic to the earthworm Pheretima peguana, NEEM decreased the body wall and epidermal thickness at Aza concentrations on filter paper of 2.35 and $3.13 \mu \mathrm{g} \mathrm{cm}^{-2}$, respectively, and increased intestinal epithelium at and above $2.35 \mu \mathrm{g} \mathrm{cm}^{-2}$ concentration. Moreover, it increased the binucleated coelomocytes at $3.13 \mu \mathrm{g} \mathrm{cm}^{-2}$ concentration. It appears that the increased intestinal wall thickness and decreased body wall 
thickness are more sensitive biomarkers of exposure to NEEM than the changes in epidermal thickness. These results suggest that along with binucleate frequency, other morphological biomarkers like morphometric and histological changes in the body wall, intestinal epithelium, and epidermis are helpful in assessing the toxicity of NEEM to earthworms.

\section{Conclusion}

NEEM containing Aza at concentrations even $>35$-fold higher than the recommended soil application rate as an insecticide was not genotoxic to earthworm coelomocytes as evidenced by the micronucleus test and comet assay. High concentrations of NEEM may be stressful, however, and earthworms adapt by changing the morphometric characters of tissues including epidermis, body wall, and intestinal epithelium. Among the parameters studied, the most sensitive biomarkers of exposure to NEEM were the increase in intestinal wall thickness and decrease in body wall thickness.

\section{Acknowledgment}

This study was supported by the Silpakorn University Research and Development Institute, Silpakorn University, Thailand.

\section{References}

[1] I. M. Scott and N. K. Kaushik, "The toxicity of Margosan$\mathrm{O}$, a product of neem seeds, to selected target and nontarget aquatic invertebrates," Archives of Environmental Contamination and Toxicology, vol. 35, no. 3, pp. 426-431, 1998.

[2] K. S. Awasthy, O. P. Chaurasia, and S. P. Sinha, "Genotoxic effects of crude extract of neem (Azadirachta indica) in bone marrow cells of mice," Cytologia, vol. 60, no. 2, pp. 189-193, 1995.

[3] P. K. Khan and K. S. Awasthy, "Cytogenetic toxicity of neem," Food and Chemical Toxicology, vol. 41, no. 10, pp. 1325-1328, 2003.

[4] P. Chandra and A. R. Khuda-Bukhsh, "Genotoxic effects of cadmium chloride and azadirachtin treated singly and in combination in fish," Ecotoxicology and Environmental Safety, vol. 58, no. 2, pp. 194-201, 2004.

[5] M. B. Bouché, "Earthworm species and ecotoxicological studies," in Ecotoxicology of Earthworms, P. W. Greig-Smith, H. Becker, P. J. Edwards, and F. Heimbach, Eds., pp. 20-35, Intercept, Andover, UK, 1992.

[6] S. A. Reinecke and A. J. Reinecke, "The comet assay as biomarker of heavy metal genotoxicity in earthworms," Archives of Environmental Contamination and Toxicology, vol. 46, no. 2, pp. 208-215, 2004.

[7] F. Fourie, S. A. Reinecke, and A. J. Reinecke, "The determination of earthworm species sensitivity differences to cadmium genotoxicity using the comet assay," Ecotoxicology and Environmental Safety, vol. 67, no. 3, pp. 361-368, 2007.

[8] R. Schlegel and J. T. MacGregor, "The persistence of micronuclei in peripheral blood erythrocytes: detection of chronic chromosome breakage in mice," Mutation Research, vol. 104, no. 6, pp. 367-369, 1982.
[9] I. Udroiu, "The micronucleus test in piscine erythrocytes," Aquatic Toxicology, vol. 79, no. 2, pp. 201-204, 2006.

[10] M. A. Farah, B. Ateeq, and W. Ahmad, "Antimutagenic effect of neem leaves extract in freshwater fish, Channa punctatus evaluated by cytogenetic tests," Science of the Total Environment, vol. 364, no. 1-3, pp. 200-214, 2006.

[11] A. V. Pavlov, M. A. Gansburgskii, A. N. Gansburgskii, M. V. Shashkina, and T. L. Miro, "The use of micronucleus test for detection of genotoxic damage to the thyroid gland," Bulletin of Experimental Biology and Medicine, vol. 141, no. 1, pp. 99102, 2006.

[12] M. Toyoshima, K. Ohno, T. Katsumoto, H. Maki, and K. Takeshita, "Cellular senescence of angiofibroma stroma cells from patients with tuberous sclerosis," Brain and Development, vol. 21, no. 3, pp. 184-191, 1999.

[13] A. Salehzadeh, A. Akhkha, W. Cushley, R. L. P. Adams, J. R. Kusel, and R. H. C. Strang, "The antimitotic effect of the neem terpenoid azadirachtin on cultured insect cells," Insect Biochemistry and Molecular Biology, vol. 33, no. 7, pp. 681689, 2003.

[14] F. L. Martin, S. Venitt, P. L. Carmichael et al., "DNA damage in breast epithelial cells: detection by the single-cell gel (comet) assay and induction by human mammary lipid extracts," Carcinogenesis, vol. 18, no. 12, pp. 2299-2305, 1997.

[15] R. R. Tice, E. Agurell, D. Anderson et al., "Single cell gel/comet assay: guidelines for in vitro and in vivo genetic toxicology testing," Environmental and Molecular Mutagenesis, vol. 35, no. 3, pp. 206-221, 2000.

[16] F. L. Martin, T. G. Piearce, A. Hewer, D. H. Phillips, and K. T. Semple, "A biomarker model of sublethal genotoxicity (DNA single-strand breaks and adducts) using the sentinel organism Aporrectodea longa in spiked soil," Environmental Pollution, vol. 138, no. 2, pp. 307-315, 2005.

[17] C. A. Edward and J. R. Lofty, Biology of Earthworms, Chapman and Hall, London, UK, 1st edition, 1972.

[18] A. Amaral, M. Soto, R. Cunha, I. Marigómez, and A. Rodrigues, "Bioavailability and cellular effects of metals on Lumbricus terrestris inhabiting volcanic soils," Environmental Pollution, vol. 142, no. 1, pp. 103-108, 2006.

[19] E. fischer and L. Molnár, "Environmental aspects of the chloragogenous tissue of earthworms," Soil Biology and Biochemistry, vol. 24, no. 12, pp. 1723-1727, 1992.

[20] A. J. Morgan, M. P. Turner, and J. E. Morgan, "Morphological plasticity in metal-sequestering earthworm chloragocytes: morphometric electron microscopy provides a biomarker of exposure in field populations," Environmental Toxicology and Chemistry, vol. 21, no. 3, pp. 610-618, 2002.

[21] N. Kaushik, "Determination of azadirachtin and fatty acid methyl esters of Azadirachta indica seeds by HPLC and GLC," Analytical and Bioanalytical Chemistry, vol. 374, no. 7-8, pp. 1124-1199, 2002.

[22] W. Kwankua, S. Sengsai, C. Kuleung, and N. Euawong, "Sunlight decreased genotoxicity of azadirachtin on root tip cells of Allium cepa and Eucrosia bicolor," Ecotoxicology and Environmental Safety, vol. 73, no. 5, pp. 949-954, 2010.

[23] G. S. Eyambe, A. J. Goven, L. C. Fitzpatrick, B. J. Venables, and E. L. Cooper, "A non-invasive technique for sequential collection of earthworm (Lumbricus terrestris) leukocytes during subchronic immunotoxicity studies," Laboratory Animals, vol. 25, no. 1, pp. 61-67, 1991.

[24] P. Brousseau, N. Fugère, J. Bernier et al., "Evaluation of earthworm exposure to contaminated soil by cytometric assay of coelomocytes phagocytosis in Lumbricus terrestris," Soil Biology and Biochemistry, vol. 29, no. 3-4, pp. 681-684, 1997. 
[25] N. P. Singh, M. T. McCoy, R. R. Tice, and E. L. Schneider, "A simple technique for quantitation of low levels of DNA damage in individual cells," Experimental Cell Research, vol. 175, no. 1, pp. 184-191, 1988.

[26] J. Homa, E. Olchawa, S. R. Stürzenbaum, A. J. Morgan, and B. Plytycz, "Early-phase immunodetection of metallothionein and heat shock proteins in extruded earthworm coelomocytes after dermal exposure to metal ions," Environmental Pollution, vol. 135, no. 2, pp. 275-280, 2005.

[27] A. Anuradha, R. S. Annadurai, and L. S. Shashidhara, "Actin cytoskeleton as a putative target of the neem limonoid azadirachtin A," Insect Biochemistry and Molecular Biology, vol. 37, no. 6, pp. 627-634, 2007.

[28] Z. Y. Wang, L. Z. Zou, B. L. Fan, and Y. K. Peng, "Abnormal metaphase cell division induced by microtubules depolymerization and photosystem II inhibiting herbicides," Cytologia, vol. 71, no. 3, pp. 289-295, 2006.

[29] J. V. Rao, P. Kavitha, and A. P. Rao, "Comparative toxicity of tetra ethyl lead and lead oxide to earthworms, Eisenia fetida (Savigny)," Environmental Research, vol. 92, no. 3, pp. 271276, 2003.

[30] N. C. Reddy and J. V. Rao, "Biological response of earthworm, Eisenia foetida (Savigny) to an organophosphorous pesticide, profenofos," Ecotoxicology and Environmental Safety, vol. 71, no. 2, pp. 574-582, 2008. 

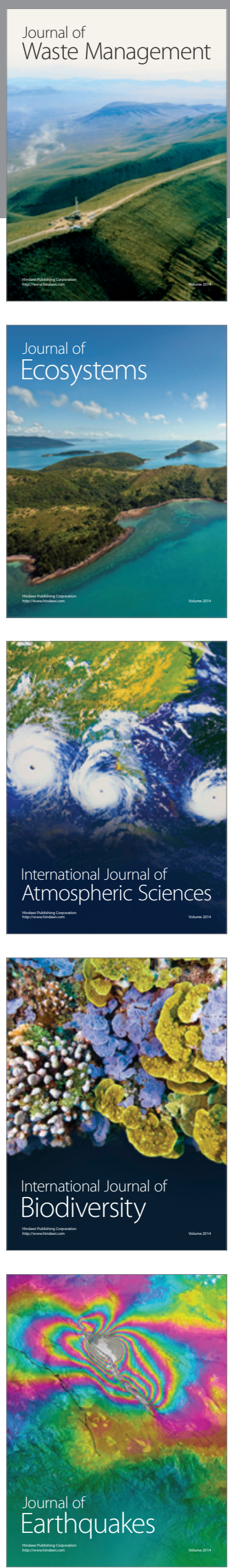
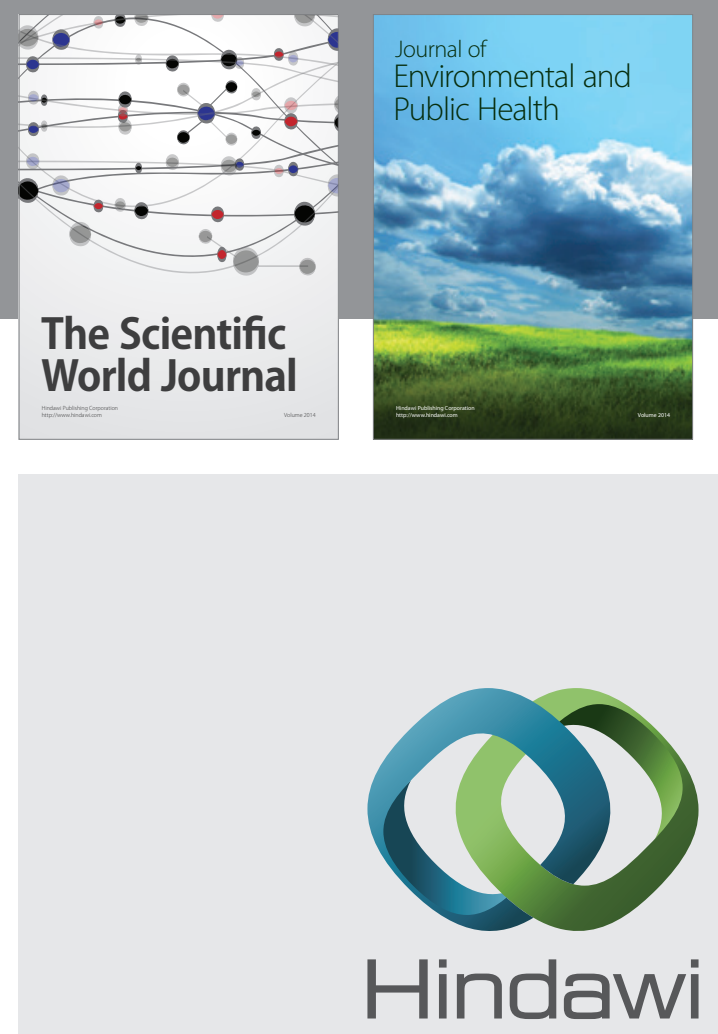

Submit your manuscripts at

http://www.hindawi.com
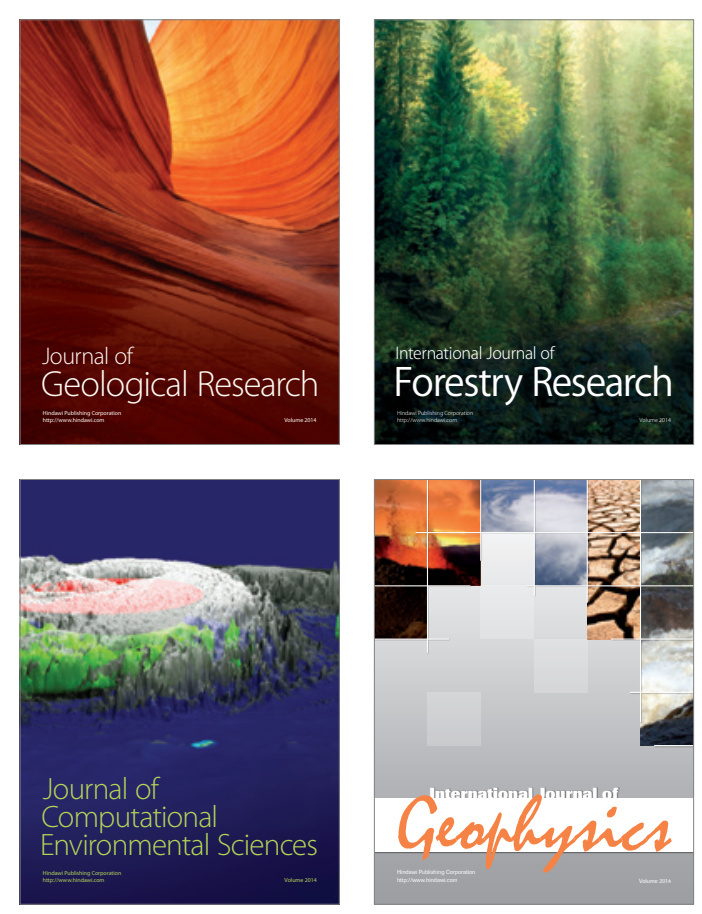
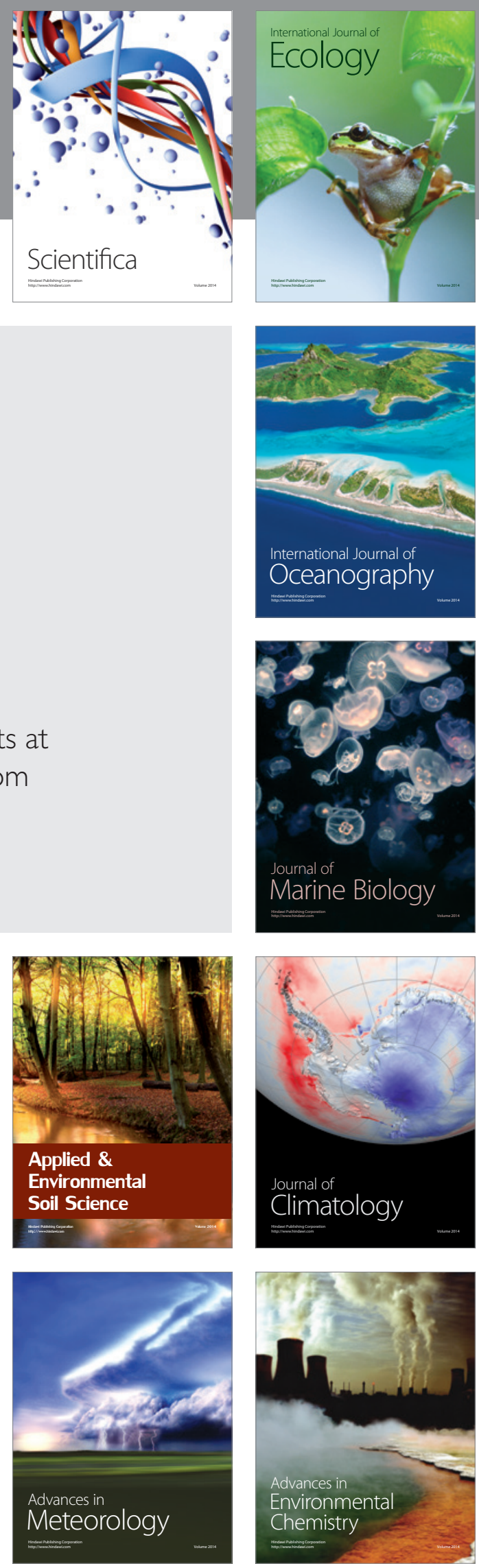